\title{
ANALISIS KAPASITAS PARKIR PADA ALFAMIDI SUPER KOTA PALOPO
}

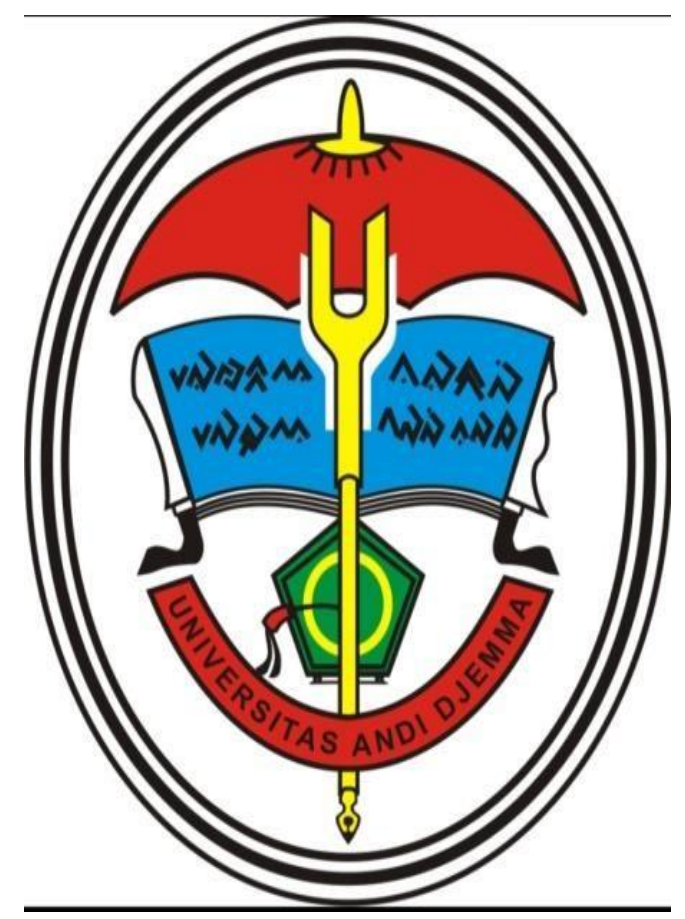

DI SUSUN OLEH :

KELOMPOK 15

1. SYAMSURI DEWANG (19.023.22.201.033)

2. M. ICHSAN RASID (19.023.22.201.005)

FAKULTAS TEKNIK

PROGRAM STUDI TEKNIK SIPIL

UNIVERSITAS ANDI DJEMMA PALOPO

2021/2022 


\section{KATA PENGANTAR}

Dengan menyebut nama Allah SWT yang Maha Pengasih lagi Maha Panyayang, Kami panjatkan puja dan puji syukur atas kehadirat-Nya, yang telah melimpahkan rahmat, hidayah, dan inayah-Nya kepada kami, sehingga kami bisa selesaikan makalah TERMINAL DAN PERPARKIRAN. Terlepas dari semua itu, Kami menyadari seutuhnya bahwa masih jauh dari kata sempurna baik dari segi susunan kalimat maupun tata bahasanya.

Oleh karena itu, kami terbuka untuk menerima segala masukan dan kritik yang bersifat membangun dari pembaca sehingga kami bisa melakukan perbaikan makalah ini sehingga menjadi makalah yang baik dan benar. Akhir kata kami meminta semoga makalah tentang terminal, memberikan manfaat ataupun inpirasi pada pembaca.

Palopo, 13 Januari 2022

penulis 


\section{ABSTRAK}

Paper ini membahas bagaimana kebutuhan parkir di Rumah Sakit Laut Kota Palopo berdasarkan survei parkir yang telah dilakukan. Survei dilakukan selama 4 hari dengan mengakomodir hari kerja dan hari libur. Paper ini merupakan tuugas mata kuliah perencanaan terminal dan perparkiran. 


\section{BAB I \\ PENDAHULUAN}

\section{A. LATAR BELAKANG}

Kendaraan angkutan umum dalam suatu wilayah. Terminal juga merupakan sarana angkutan yang ramai sekali dengan kegiatan-kegiatan masyarakat Terminal adalah prasarana transportasi jalan untuk keperluan memuatdanmenurunkan barang, serta mengatur kedatangan dan keberangkatan di umum. Keberadaan terminal berperan dalam menentukan tingkat kinerja dari pelayanan alamnya,maka sudah menjadi kebiasaan seperti, kemacetan, kepadatan kendaraan, ketidak tertiban lalu lintas khususnya kendaraan berjenis angkutan kota atau angkot masyarakat menyebutnya. Angkutan kota atau angkot adalah sebuah moda transportasi perkotaan yang merujuk kepada kendaraan umum dengan rute yang sudah ditentukan, tidak seperti bus yang mempunyai halte sebagai tempat dan peraturan yang berlaku di kawasan terminal, sehingga menambah kemacetan dan kepadatan kendaraan di kawasan tersebut akibat angkutan kota yang tidak disiplin. Apalagi pada saat jam-jam tertentu seperti jam masuk kerja, dan pulang kerja, jalanan akan sangat padat dan macet di tambah angkutan kota yang tidak tertib. perhentian yang sudah ditentukan, sama halnya dengan angkutan umum atau angkutan kota khususnya di kawasan terminal angkutan kota Leuwi Panjang, beberapa angkutan kota yang tidak patuh akan tata tertib. 
Perparkiran adalah salah satu masalah yang sering sekali dijumpai dalam hal transportasi, terutama dalam penyebab kemacetan yang sedang merajalela di berbagai kota besar yang sedang berkembang, begitupun Indonesia. Perparkiran menjadi fenomena yang mempengaruhi pergerakan kendaraan disaat kendaraan-kendaraan yang mempunyai intensitas pergerakan yang begitu tinggi akan terhambat oleh kendaraan yang parkir di bahu jalan sehingga menyebabkan kemacetan. Pada umumnya kendaraan yang parkir di pinggir jalan berada di sekitar tempat atau pusat kegiatan seperti : sekolah, kantor, pasar swalayan, pasar tradisional, rumah makan, dan lain-lain. Usaha yang perlu dilakukan untuk menangani masalah perparkiran tersebut, diperlukan pengadaan lahan parkir yang cukup memadai dan pembentukan model lahan parkir yang tepat pada lahan parkir yang tersedia, mengingat kebutuhan akan lahan parkir (demand) dan prasarana yang dibutuhkan (supply) harus seimbang dengan karakteristik perparkiran. Parkir semestinya hanya digunakan untuk memberhentikan kendaraan untuk sementara, tidak dalam waktu lama atau bahkan berhari - hari yang dilakukan.Penggunaan parkir sesuai peraturan yang rapi akan memudahkan petugas parkir dalam memarkirkan kendaraan. Dapat digaris bawahi bahwa kegiatan parkir tersebut seharusnya tidak mengganggu pergerakan ruang lalu lintas dan juga tidak mengganggu pejalan kaki, tapi pada kenyataannya 
perparkiran yang selama ini berlangsung terutama on street parking sering menghambat pergerakan lalu lintas, sehingga terjadilah kemacetan. Hal ini dikarenakan pemakaian lahan parkir yang tidak seharusnya. Contoh dari pemakaian lahan parkir yang tidak seharusnya adalah karena kendaraan parkir yang tidak diparkirkan dengan benar,kendaraan tidak diparkirkan sesuai dengan posisi parkir yang sudah ditandai dengan marka parkir.

\section{B. RUMUSAN MASALAH}

1. Bagaimanakah kondisi penggunaan parkir di Alfamidi Super?

\section{TUJUAN}

1. Untuk mengetahui apa itu terminal dan perparkiran dalam kehidupan sehari - hari ?

2. Untuk mengetahui kondisi dalam jangka waktu tertentu terminal dan perparkiran yang ada di Alfamidi Super. 


\section{BAB II \\ LANDASAN TEORI}

\section{A.PERPARKIRAN}

\section{Pengertian}

Parkir adalah lalu lintas berhenti yang ditinggal pengemudi saat mencapaisuatu tempat tujuan dengan jangka waktu tertentu. Perilaku pengendara kendaraan bermotor memiliki kecenderungan untuk memarkir kendaraannya tidak jauhdengan tempat kegiatannya.

Menurut Direktorat Jenderal Perhubungan Darat (1998), ada beberapa pengertian tentang perparkiran bahwa :

- Parkir adalah keadaan tidak bergerak suatu kendaraan yang tidak bersifat sementara

- Berhenti adalah keadaan tidak bergerak suatu kendaraan untuk sementara dengan pengemudi tidak meninggalkan kendaraan

- Fasilitas parkir adalah lokasi yang ditentukan sebagai tempat pemberhentian kendaraan yang tidak bersifat sementara untuk melakukan kegiatan pada suatu kurun waktu tertentu

- Fasilitas parkir di badan jalan (on-street parking) adalah fasilitas parkir yang menggunakan tepi jalan

- Fasilitas parkir di luar badan jalan ( off-street parking) adalah fasilitas parkir kendaraan di luar tepi jalan umum yang dibuat khusus atau penunjang kegiatan yang dapat berupa tempat parkir atau gedung parkir.

Pada perencanaan terminal dan lokasi parkir yang baik adalah yang perencanaan lokasinya secara sistem jaringan mampu berperan dalam melancarkan pergerakan sistem transportasi secara keseluruhan, dengan demikian perencanaan dan pengembangannya perlu ditata dalam satu kesatuan sistem yang terpadu (Fisu, 2018).

Perencanaan sistem angkutan yang dibuat tanpa pertimbangan matang akan berdampak pad apola pergerakan, arus lalu lintas perkotaan, bahkan hingga menyebabkan kecelakaan lalu lintas (Fisu, 2019). 


\section{Fasilitas Parkir}

Menurut Joseph Dechiara \& Lee Koppelmen, 1975 (dalam Ririh Sudiraharjo), fasilitas parkir dan jenis parkir menurut penempatannya, yaitu

a. Parkir di tepi jalan (on street parking)

Parkir di tepi jalan adalah parkir yang mengambil tempat di sepanjang jalan dengan atau tanpa melebarkan jalan untuk pembatas parkir. Jenis parkir ini baik untuk pengunjung yang ingin dekat dengan tempat tujuannya.

b. Parkir tidak di tepi jalan (off street parking)

Cara ini menempati pelataran tertentu di luar badan jalan baik di

halaman terbuka atau dalam bangunan khusus untuk parkir dan mempunyai pintu pelayanan masuk untuk mengambil karcis parkir sehingga dapat diketahui jumlah kendaraan yang parkir dan jangka waktu kendaraan parkir.

Adapun pengaruh besaran ruang parkir adalah sebagai berikut :

1. Ruang bebas kendaraan parkir

Untuk sepeda motor, biasanya ruang bebas arah samping diambil $2 \mathrm{~cm}$ dan arah memanjang $20 \mathrm{~cm}$.

2. Lebar bukaan pintu kendaraan

Ukuran lebar bukaan pintu merupakan fungsi karakteristik pemakai kendaraan yang memanfaatkan fasilitas parkir. Karakteristik pengguna kendaraan yang memanfaatkan fasilitas parkir dibagi menjadi tiga seperti yang ditunjukkan pada table dibawah ini. 
Tabel lebar bukaan pintu kendaraan

\begin{tabular}{|l|l|c|}
\hline Jenis bukaan pintu & $\begin{array}{l}\text { Pengguna dan atau } \\
\text { Peruntukan fasilitas } \\
\text { parkir }\end{array}$ & Golongan \\
\hline $\begin{array}{l}\text { Pintu depan/belakang } \\
\text { Terbuka tahap awal } \\
55 \mathrm{~cm}\end{array}$ & $\begin{array}{l}\text { Karyawan/ pekerja } \\
\text { Kantor tamu/pengunjung } \\
\text { Pusat kegiatan perkantoran } \\
\text { Perdagangan,eceran rumah } \\
\text { Sakit,bioskop }\end{array}$ & I \\
\hline $\begin{array}{l}\text { Pintu depan/belakang } \\
\text { Terbuka penuh } 75 \mathrm{~cm}\end{array}$ & $\begin{array}{l}\text { Pengunjung tempat olahraga, } \\
\text { Pusat hiburan rekreasi,hotel, } \\
\text { Pusat perdagangan eceran } \\
\text { Swalayan,rumah sakit,bioskop. }\end{array}$ & II \\
\hline $\begin{array}{l}\text { Pintu depan terbuka } \\
\text { Penuh dan ditambah } \\
\text { Untuk pergerakan } \\
\text { Kursi roda }\end{array}$ & Orang cacat & III \\
\hline
\end{tabular}

3. Penentuan satuan ruang parkir (SRP)

Berdasarkan Tabel 3.1 penentuan Satuan Ruang Parkir (SRP) dibagi atas tiga jenis kendaraan dan berdasarkan penentuan SRP untuk mobil penumpang diklassifikasikan menjadi tiga golongan, seperti Tabel 3.2.

Tabel Penentuan Satuan Ruang Parkir

\begin{tabular}{|l|c|}
\hline \multicolumn{1}{|c|}{ Jenis kendaraan } & SRP $(\mathrm{m}$ persegi $)$ \\
\hline $\begin{array}{l}\text { 1.a. mobil penumpang untuk } \\
\text { Golongan I } \\
\text { b. Mobil penumpang untuk } \\
\text { golongan II }\end{array}$ & $2.3 \times 5.0$ \\
$\begin{array}{l}\text { c. Mobil penumpang untuk } \\
\text { golongan III }\end{array}$ & $2.5 \times 5.0$ \\
\hline 2.Bus atau truk & $3.0 \times 5.0$ \\
\hline 3.Sepeda motor & $3.4 \times 12.5$ \\
\hline
\end{tabular}




\section{Standar Kebutuhan Ruang Parkir :}

Standar kebutuhan luas area kegiatan parkir berbeda antara satu dengan yang lain tergantung pada beberapa hal antara lain pelayanan, tarif yang diberlakukan, ketersediaan ruang parkir, tingkat pemilikan kendaraan bermotor, tingkat pendapatan masyarakat. Be rdasarkan hasil studi Direktorat Jenderal 17 Perhubungan Darat, kegiatan dan standar -standar kebutuhan parkir adalah sebagai berikut :

Kegiatan parkir tetap :

Kegiatan parkir tetap meliputi $\mathrm{p}$ usat perdagangan, pusat perkantoran swasta atau pemerintahan, sekolah/perguruan tinggi, hotel dan tempat penginapan, rumah sakit, pasar swalayan atau pusat perdagangan eceran, dan tempat rekreasi. Kecenderungan kegiatan parkir tetap pada Kawasan Malioboro adalah pasar swalayan atau pusat perdagangan eceran dan tempat rekreasi.

1. Pasar swalayan atau pusat perdangangan eceran

\begin{tabular}{|l|c|c|c|c|c|c|c|c|c|}
\hline $\begin{array}{l}\text { Luas area } \\
\text { total } 100 \mathrm{~m}\end{array}$ & 50 & 75 & 100 & 150 & 200 & 300 & 400 & 500 & 1000 \\
\hline $\begin{array}{l}\text { Kebutuhan } \\
\text { (srp) }\end{array}$ & 225 & 250 & 270 & 310 & 350 & 440 & 520 & 600 & 1050 \\
\hline
\end{tabular}

2. Tempat rekreasi

\begin{tabular}{|l|l|l|l|l|l|l|l|l|l|}
\hline $\begin{array}{l}\text { Luas area } \\
\text { total } 100 \mathrm{~m}\end{array}$ & 50 & 100 & 150 & 200 & 400 & 800 & 1600 & 3200 & 6400 \\
\hline $\begin{array}{l}\text { Kebutuhan } \\
\text { (SRP) }\end{array}$ & 103 & 109 & 115 & 122 & 146 & 196 & 295 & 494 & 892 \\
\hline
\end{tabular}


Kegiatan Parkir yang Bersifat Sementara :

Kegiatan parkir bersifat sementara yang durasi parkirnya 1,5 sampai 2 jam saja yang meliputi bioskop/gedung pertunjukan, tempat pertandingan olahraga.

Kebutuhan ruang parkir dapat dilihat pada tabel.

\begin{tabular}{|c|c|c|}
\hline peruntukan & $\begin{array}{l}\text { Satuan (SRP untuk mobil } \\
\text { Penumpang) }\end{array}$ & $\begin{array}{l}\text { Kebutuhan ruang } \\
\text { parkir }\end{array}$ \\
\hline $\begin{array}{l}\text { Pusat perdangan } \\
\text { - Pertokohan } \\
\text { - Pasar swalayan } \\
\text { - pasar }\end{array}$ & $\begin{array}{l}\text { SRP / } 100 \mathrm{~m} \text { luas } \\
\text { lantai Efektif } \\
\text { SRP / } 100 \mathrm{~m} \text { luas } \\
\text { lantai Efektif } \\
\text { SRP / } 100 \mathrm{~m} \text { luas } \\
\text { lantai Efektif }\end{array}$ & $\begin{array}{l}3,5-7,5 \\
3,5-7,5 \\
3,5-7,5\end{array}$ \\
\hline $\begin{array}{l}\text { Pusat perkantoran } \\
\text { - pelayanan bukan } \\
\text { umum } \\
\text { - pelayanan umum }\end{array}$ & $\begin{array}{l}\text { SRP / } 100 \text { m luas } \\
\text { lantai Efektif } \\
\text { SRP / } 100 \text { m luas } \\
\text { lantai Efektif }\end{array}$ & $\begin{array}{l}1,5-3,5 \\
1,5-3,5\end{array}$ \\
\hline $\begin{array}{l}\text { Sekolah } \\
\text { Hotel/tempat } \\
\text { penginapan dan rumah } \\
\text { sakit } \\
\text { Bioskop/gedung } \\
\text { pertunjukan }\end{array}$ & $\begin{array}{l}\text { SRP / } \\
\text { mahasiswa SRP } \\
\text { / kamar } \\
\text { SRP / tempat tidur } \\
\text { SRP / tempat duduk }\end{array}$ & $\begin{array}{l}0,7-1,0 \\
0,2-1,0 \\
0,2-1,3 \\
0,2-0,4\end{array}$ \\
\hline
\end{tabular}




\section{BAB III \\ PEMBAHASAN}

1. LOKASI PENGAMATAN ( Alfamidi Super )

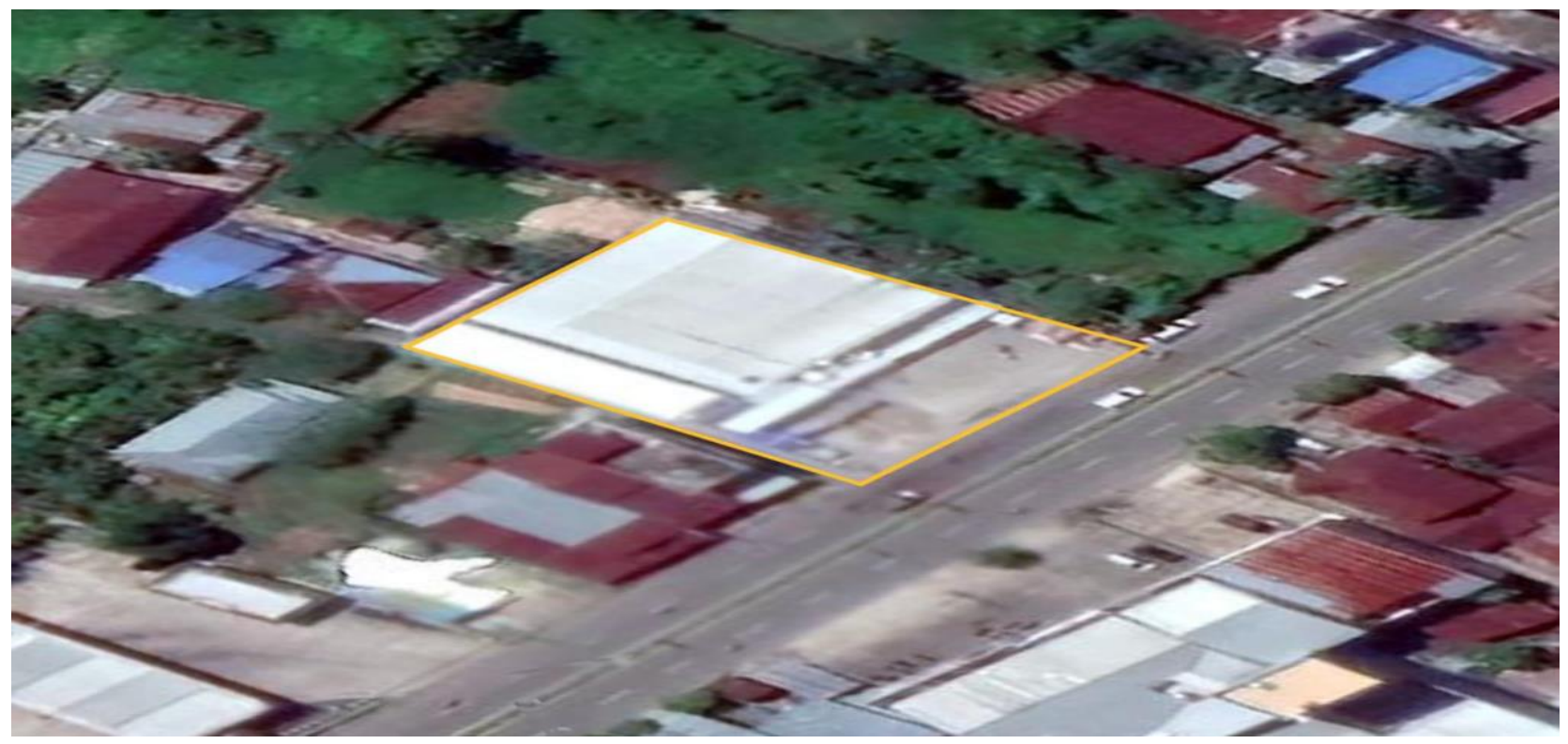

Deskripsi : Alfamidi Super terletak di jl. Jend Sudirman, Binturu, Wara Sel., Kota Palopo, Sulawesi Selatan 91923, Indonesia

Salah satu Alfamidi di Palopo ini menyediakan berbagai kebutuhan sehari-hari seperti buah, sayur, makanan, susu, minuman, cemilan hingga sabun dan shampo. ALFA MIDI ini juga menyediakan diskon dan promo Alfamidi setiap harinya, ada juga promo perminggu (weekend), promo bulanan dan promo JSM Alfamidi. Terdapat juga bentuk promosi berbentuk voucher belanja sehingga harga produk di Alfamidi menjadi murah dan terjangkau.

Selain dari berbelanja kebutuhan sehari-hari, gerai Alfamidi Palopo juga melayani berbagai kebutuhan pembayaran seperti pembayaran tiket online, pembayaran iuran BPJS di Alfamidi, pembayaran telepon, pembayaran listrik (token) di Alfamidi, dan pembelian pulsa. Kunjungi Alfamidi terdekat ini pada jam kerja / buka untuk informasi katalog Alfamidi, katalog promosi, daftar harga / price list, dan lainnya.. 


\section{KONDISI PARKIRAN (Alfamidi Super)}

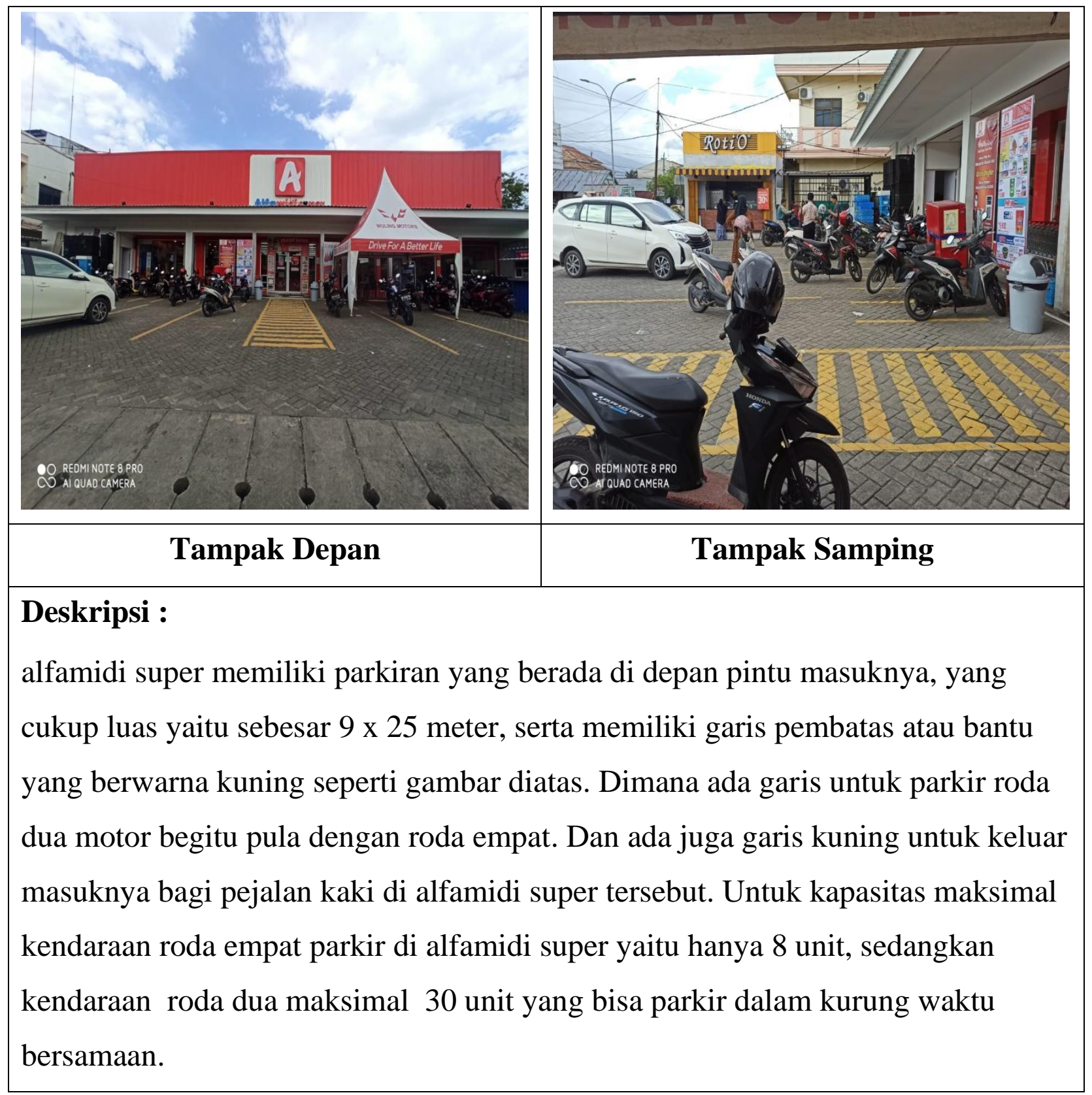




\section{DOKUMENTASI}

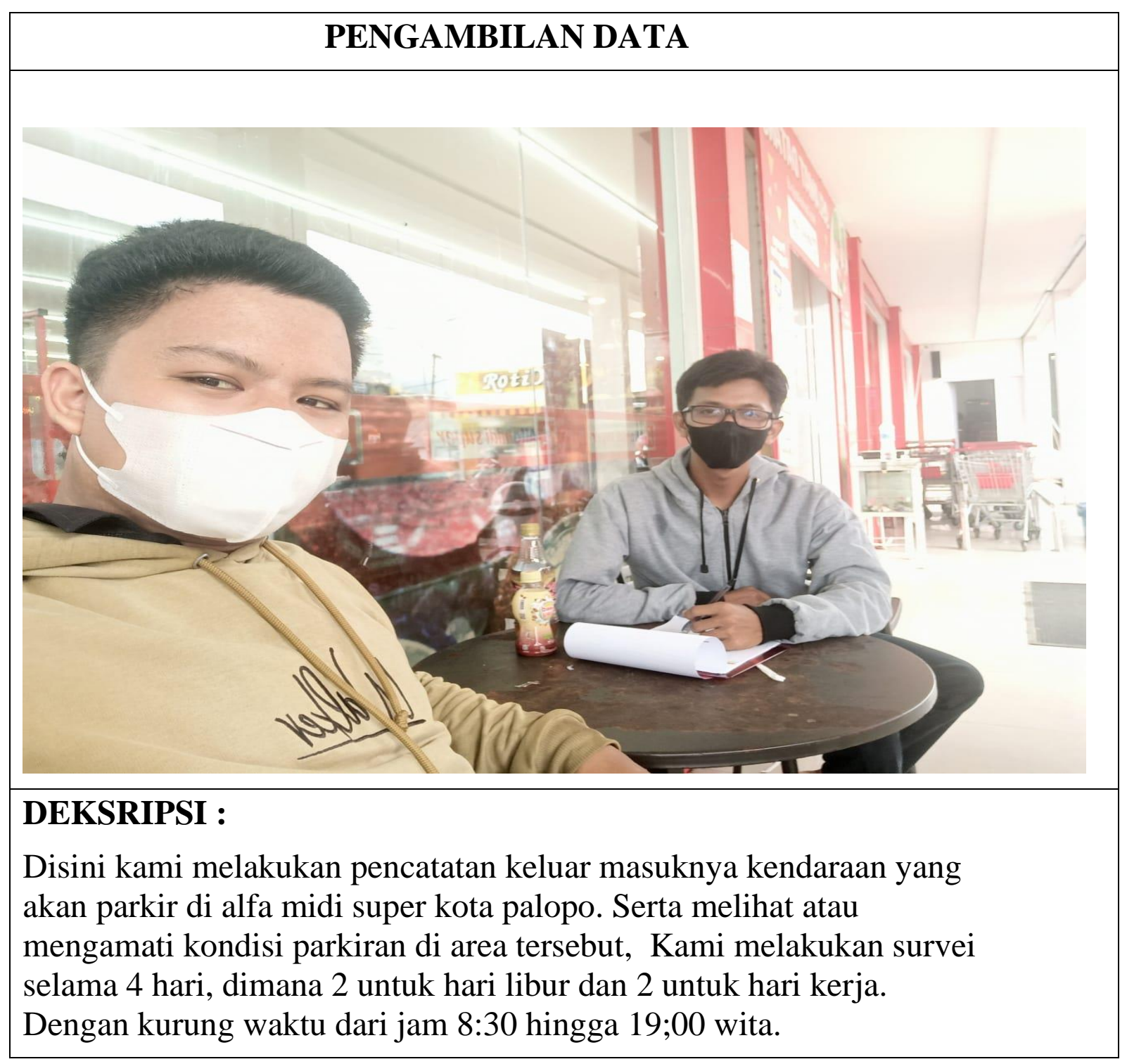




\section{HASIL SURVEY SELAMA 4 HARI}

\section{A. HARI LIBUR}

(SABTU, 11 DESEMBER 2021)

TABEL PER 15 MENIT

\begin{tabular}{|c|c|c|c|c|c|c|c|}
\hline \multirow{2}{*}{ No. } & \multirow{2}{*}{$\begin{array}{l}\text { INTERVAL WAKTU } \\
\text { PENGAMATAN }\end{array}$} & \multicolumn{3}{|c|}{ MOTOR } & \multicolumn{3}{|c|}{ MOBIL } \\
\hline & & MASUK & KELUAR & TERTINGGAL & MASUK & KELUAR & TERTINGGAL \\
\hline \multicolumn{4}{|c|}{$<08: 30$} & 5 & & & 2 \\
\hline 1 & $08: 30-08: 45$ & 15 & 15 & 5 & 2 & 1 & 3 \\
\hline 2 & 08:45 - 09:00 & 16 & 17 & 4 & 2 & 3 & 2 \\
\hline 3 & 09:00 - 09:15 & 18 & 17 & 5 & 4 & 2 & 4 \\
\hline 4 & $09: 15$ - 09:30 & 12 & 8 & 9 & 1 & 3 & 2 \\
\hline 5 & $09: 30$ - 09:45 & 8 & 8 & 9 & 5 & 4 & 3 \\
\hline 6 & $09: 45$ - 10:00 & 12 & 11 & 10 & 3 & 4 & 2 \\
\hline 7 & $10: 00-10: 15$ & 9 & 8 & 11 & 2 & 3 & 1 \\
\hline 8 & $10: 15-10: 30$ & 14 & 13 & 12 & 6 & 3 & 4 \\
\hline 9 & $10: 30$ - 10:45 & 8 & 8 & 12 & 3 & 4 & 3 \\
\hline 10 & $10: 45-11: 00$ & 11 & 12 & 11 & 3 & 4 & 2 \\
\hline 11 & $11: 00-11: 15$ & 7 & 6 & 12 & 5 & 3 & 4 \\
\hline 12 & $11: 15-11: 30$ & 9 & 7 & 14 & 4 & 4 & 4 \\
\hline 13 & $11: 30$ - 11:45 & 7 & 8 & 13 & 2 & 3 & 3 \\
\hline 14 & $11: 45-12: 00$ & 10 & 12 & 11 & 6 & 5 & 4 \\
\hline 15 & $12: 00-12: 15$ & 12 & 15 & 8 & 3 & 5 & 2 \\
\hline 16 & $12: 15-12: 30$ & 8 & 10 & 6 & 7 & 6 & 3 \\
\hline 17 & $12: 30-12: 45$ & 11 & 8 & 9 & 3 & 4 & 2 \\
\hline 18 & $12: 45-13: 00$ & 7 & 9 & 7 & 4 & 4 & 2 \\
\hline 19 & $13: 00-13: 15$ & 9 & 7 & 9 & 3 & 5 & 0 \\
\hline 20 & $13: 15-13: 30$ & 10 & 7 & 12 & 3 & 2 & 1 \\
\hline 21 & $13: 30-13: 45$ & 7 & 7 & 12 & 5 & 2 & 4 \\
\hline 22 & $13: 45-14: 00$ & 11 & 13 & 10 & 4 & 4 & 4 \\
\hline 23 & $14: 00-14: 15$ & 8 & 10 & 8 & 6 & 7 & 3 \\
\hline 24 & $14: 15-14: 30$ & 10 & 8 & 10 & 4 & 5 & 2 \\
\hline 25 & $14: 30-14: 45$ & 8 & 7 & 11 & 2 & 4 & 0 \\
\hline 26 & $14: 45-15: 00$ & 7 & 5 & 13 & 3 & 3 & 0 \\
\hline 27 & $15: 00-15: 15$ & 13 & 15 & 11 & 5 & 3 & 2 \\
\hline 28 & $15: 15-15: 30$ & 10 & 8 & 13 & 3 & 4 & 1 \\
\hline 29 & $15: 30-15: 45$ & 10 & 12 & 11 & 4 & 4 & 1 \\
\hline 30 & $15: 45-16: 00$ & 8 & 10 & 9 & 3 & 4 & 0 \\
\hline 31 & $16: 00-16: 15$ & 10 & 7 & 12 & 5 & 2 & 3 \\
\hline 32 & $16: 15-16: 30$ & 9 & 8 & 13 & 3 & 2 & 4 \\
\hline 33 & $16: 30-16: 45$ & 8 & 11 & 10 & 4 & 6 & 2 \\
\hline 34 & $16: 45$ - 17:00 & 11 & 12 & 9 & 5 & 6 & 1 \\
\hline 35 & $17: 00$ - 17:15 & 8 & 10 & 7 & 3 & 2 & 2 \\
\hline 36 & $17: 15-17: 30$ & 8 & 6 & 9 & 2 & 3 & 1 \\
\hline 37 & $17: 30-17: 45$ & 10 & 7 & 12 & 5 & 2 & 4 \\
\hline 38 & $17: 45-18: 00$ & 12 & 15 & 9 & 3 & 4 & 3 \\
\hline 39 & $18: 00-18: 15$ & 11 & 10 & 10 & 4 & 4 & 3 \\
\hline 40 & $18: 15-18: 30$ & 13 & 10 & 13 & 5 & 4 & 4 \\
\hline 41 & $18: 30-18: 45$ & 10 & 11 & 12 & 4 & 5 & 3 \\
\hline 42 & $18: 45-19: 00$ & 9 & 10 & 11 & 5 & 6 & 2 \\
\hline & Total & 424 & 418 & 429 & 158 & 158 & 102 \\
\hline & Rata-Rata & 10 & 10 & 10 & 4 & 4 & 2 \\
\hline
\end{tabular}




\begin{tabular}{|c|c|c|c|c|c|c|c|}
\hline \multirow{2}{*}{ NO. } & \multirow{2}{*}{ WAKTU } & \multicolumn{3}{|c|}{ MOTOR } & \multicolumn{3}{c|}{ MOBIL } \\
\cline { 3 - 8 } & & MASUK & KELUAR & TERTINGGAL & MASUK & KELUAR & TERTINGGAL \\
\hline \hline 1 & $08: 30-09: 00$ & 31 & 32 & 4 & 4 & 4 & 2 \\
\hline 2 & $09: 00-10: 00$ & 50 & 44 & 10 & 13 & 13 & 2 \\
\hline 3 & $10: 00-11: 00$ & 42 & 41 & 11 & 14 & 14 & 2 \\
\hline 4 & $11: 00-12: 00$ & 33 & 33 & 11 & 17 & 15 & 4 \\
\hline 5 & $12: 00-13: 00$ & 38 & 42 & 7 & 17 & 19 & 2 \\
\hline 6 & $13: 00-14: 00$ & 37 & 34 & 10 & 15 & 13 & 4 \\
\hline 7 & $14: 00-15: 00$ & 33 & 30 & 13 & 15 & 19 & 0 \\
\hline 8 & $15: 00-16: 00$ & 41 & 45 & 9 & 15 & 15 & 0 \\
\hline 9 & $16: 00-17: 00$ & 38 & 38 & 9 & 17 & 16 & 1 \\
\hline 10 & $17: 00-18: 00$ & 38 & 38 & 9 & 13 & 11 & 3 \\
\hline 11 & $18: 00-19: 00$ & 43 & 41 & 11 & 18 & 19 & 2 \\
\hline
\end{tabular}

\section{ANALISIS :}

Dilihat dari tabel di atas kendaraan beroda dua lebih banyak dibanding roda empat, apabila diamati secara sepintas terdapat beberapa waktu yang kendaraan beroda dua maupun empat padat masuk ke lokasi. Akan tetapi dilihat dari akumulasi kendaraan ((kendaraan terparkir+kendaraan yang masuk)-kendaraan yang keluar), waktu padat per 1 jam kendaraan yaitu pada waktu 09.0010.00 wita. 


\section{(MINGGU, 12 DESEMBER 2021)}

\section{TABEL PER 15 MENIT}

\begin{tabular}{|c|c|c|c|c|c|c|c|}
\hline \multirow{2}{*}{ No. } & \multirow{2}{*}{\begin{tabular}{|c|} 
INTERVAL WAKTU \\
PENGAMATAN
\end{tabular}} & \multicolumn{3}{|c|}{ MOTOR } & \multicolumn{3}{|c|}{ MOBIL } \\
\hline & & MASUK & KELUAR & TERTINGGAL & MASUK & KELUAR & TERTINGGAL \\
\hline \multicolumn{4}{|c|}{$<08: 30$} & \multirow{2}{*}{$\frac{7}{6}$} & & & 3 \\
\hline 1 & $08: 30-08: 45$ & 8 & 9 & & 4 & 5 & 2 \\
\hline 2 & 08:45 - 09:00 & 11 & 8 & 9 & 4 & 4 & 2 \\
\hline 3 & 09:00 - 09:15 & 10 & 10 & 9 & 6 & 6 & 2 \\
\hline 4 & 09:15 - 09:30 & 12 & 14 & 7 & 3 & 4 & 1 \\
\hline 5 & 09:30 - 09:45 & 10 & 10 & 7 & 5 & 3 & 3 \\
\hline 6 & 09:45 - 10:00 & 13 & 8 & 12 & 7 & 6 & 4 \\
\hline 7 & $10: 00$ - 10:15 & 7 & 11 & 8 & 3 & 5 & 2 \\
\hline 8 & $10: 15-10: 30$ & 13 & 7 & 14 & 6 & 3 & 5 \\
\hline 9 & $10: 30-10: 45$ & 8 & 9 & 13 & 3 & 3 & 5 \\
\hline 10 & $10: 45-11: 00$ & 5 & 7 & 11 & 5 & 7 & 3 \\
\hline 11 & $11: 00-11: 15$ & 10 & 8 & 13 & 4 & 6 & 1 \\
\hline 12 & $11: 15-11: 30$ & 12 & 10 & 15 & 4 & 3 & 2 \\
\hline 13 & $11: 30-11: 45$ & 9 & 11 & 13 & 3 & 3 & 2 \\
\hline 14 & $11: 45-12: 00$ & 10 & 9 & 14 & 5 & 3 & 4 \\
\hline 15 & $12: 00-12: 15$ & 9 & 12 & 11 & 4 & 6 & 2 \\
\hline 16 & $12: 15-12: 30$ & 12 & 10 & 13 & 6 & 6 & 2 \\
\hline 17 & $12: 30-12: 45$ & 10 & 8 & 15 & 5 & 3 & 4 \\
\hline 18 & $12: 45-13: 00$ & 8 & 11 & 12 & 4 & 6 & 2 \\
\hline 19 & $13: 00-13: 15$ & 7 & 10 & 9 & 3 & 4 & 1 \\
\hline 20 & $13: 15-13: 30$ & 8 & 7 & 10 & 4 & 4 & 1 \\
\hline 21 & $13: 30-13: 45$ & 14 & 15 & 9 & 3 & 3 & 1 \\
\hline 22 & $13: 45-14: 00$ & 7 & 11 & 5 & 4 & 2 & 3 \\
\hline 23 & $14: 00-14: 15$ & 14 & 7 & 12 & 3 & 2 & 4 \\
\hline 24 & $14: 15-14: 30$ & 7 & 8 & 11 & 2 & 4 & 2 \\
\hline 25 & $14: 30-14: 45$ & 13 & 14 & 10 & 1 & 2 & 1 \\
\hline 26 & $14: 45-15: 00$ & 6 & 9 & 7 & 4 & 3 & 2 \\
\hline 27 & $15: 00-15: 15$ & 13 & 10 & 10 & 5 & 6 & 1 \\
\hline 28 & $15: 15-15: 30$ & 11 & 9 & 12 & 4 & 3 & 2 \\
\hline 29 & $15: 30-15: 45$ & 7 & 10 & 9 & 3 & 1 & 4 \\
\hline 30 & $15: 45-16: 00$ & 15 & 14 & 10 & 9 & 8 & 5 \\
\hline 31 & $16: 00$ - 16:15 & 10 & 8 & 12 & 6 & 7 & 4 \\
\hline 32 & $16: 15-16: 30$ & 14 & 12 & 14 & 4 & 3 & 5 \\
\hline 33 & $16: 30-16: 45$ & 17 & 15 & 16 & 5 & 6 & 4 \\
\hline 34 & $16: 45-17: 00$ & 11 & 10 & 17 & 6 & 7 & 3 \\
\hline 35 & $17: 00-17: 15$ & 6 & 12 & 11 & 4 & 5 & 2 \\
\hline 36 & $17: 15-17: 30$ & 11 & 15 & 7 & 3 & 2 & 3 \\
\hline 37 & $17: 30-17: 45$ & 16 & 10 & 13 & 4 & 7 & 0 \\
\hline 38 & $17: 45-18: 00$ & 7 & 14 & 6 & 4 & 3 & 1 \\
\hline 39 & $18: 00-18: 15$ & 11 & 8 & 9 & 4 & 3 & 2 \\
\hline 40 & $18: 15-18: 30$ & 8 & 7 & 10 & 5 & 4 & 3 \\
\hline 41 & $18: 30-18: 45$ & 14 & 15 & 9 & 4 & 3 & 4 \\
\hline 42 & 18:45 - 19:00 & 11 & 10 & 10 & 6 & 5 & 5 \\
\hline & Total & 435 & 432 & 457 & 181 & 179 & 114 \\
\hline & Rata-Rata & 10 & 10 & 11 & 4 & 4 & 3 \\
\hline
\end{tabular}




\begin{tabular}{|c|c|c|c|c|c|c|c|}
\hline \multirow{2}{*}{ NO. } & \multirow{2}{*}{ WAKTU } & \multicolumn{3}{|c|}{ MOTOR } & \multicolumn{3}{c|}{ MOBIL } \\
\cline { 3 - 8 } & & MASUK & KELUAR & TERTINGGAL & MASUK & KELUAR & TERTINGGAL \\
\hline \hline 1 & $08: 30-09: 00$ & 19 & 17 & 9 & 8 & 9 & 2 \\
\hline 2 & $09: 00-10: 00$ & 45 & 42 & 12 & 21 & 19 & 4 \\
\hline 3 & $10: 00-11: 00$ & 33 & 34 & 11 & 17 & 18 & 3 \\
\hline 4 & $11: 00-12: 00$ & 41 & 38 & 14 & 16 & 15 & 4 \\
\hline 5 & $12: 00-13: 00$ & 39 & 41 & 12 & 19 & 21 & 2 \\
\hline 6 & $13: 00-14: 00$ & 36 & 43 & 5 & 14 & 13 & 3 \\
\hline 7 & $14: 00-15: 00$ & 40 & 38 & 7 & 10 & 11 & 2 \\
\hline 8 & $15: 00-16: 00$ & 46 & 43 & 10 & 21 & 18 & 5 \\
\hline 9 & $16: 00-17: 00$ & 52 & 45 & 17 & 21 & 23 & 3 \\
\hline 10 & $17: 00-18: 00$ & 40 & 51 & 6 & 15 & 17 & 1 \\
\hline 11 & $18: 00-19: 00$ & 44 & 40 & 10 & 19 & 15 & 5 \\
\hline
\end{tabular}

\section{ANALISIS :}

Dilihat dari tabel di atas kendaraan beroda dua lebih banyak dibanding roda empat, apabila diamati secara sepintas terdapat beberapa waktu yang kendaraan beroda dua maupun empat padat masuk ke lokasi. Akan tetapi dilihat dari akumulasi kendaraan ((kendaraan terparkir+kendaraan yang masuk)-kendaraan yang keluar), waktu padat per 1 jam kendaraan yaitu pada waktu 16.0017.00 wita. 


\section{B. HARI KERJA}

(SENIN, 13 DESEMBER 2021)

\section{TABEL PER 15 MENIT}

\begin{tabular}{|c|c|c|c|c|c|c|c|}
\hline \multirow{2}{*}{ NO. } & \multirow{2}{*}{$\begin{array}{l}\text { INTERVAL WAKTU } \\
\text { PENGAMATAN }\end{array}$} & \multicolumn{3}{|c|}{ MOTOR } & \multicolumn{3}{|c|}{ MOBIL } \\
\hline & & MASUK & KELUAR & TERTINGGAL & MASUK & KELUAR & TERTINGGAL \\
\hline \multicolumn{4}{|c|}{$<08: 30$} & 7 & & & 3 \\
\hline 1 & $08: 30$ - 08:45 & 9 & 8 & 8 & 2 & 2 & 3 \\
\hline 2 & 08:45 - 09:00 & 11 & 8 & 11 & 3 & 2 & 4 \\
\hline 3 & 09:00 - 09:15 & 14 & 12 & 13 & 8 & 9 & 3 \\
\hline 4 & 09:15 - 09:30 & 15 & 15 & 13 & 4 & 6 & 1 \\
\hline 5 & 09:30 - 09:45 & 15 & 14 & 14 & 5 & 4 & 2 \\
\hline 6 & 09:45 - 10:00 & 18 & 17 & 15 & 3 & 2 & 3 \\
\hline 7 & 10:00 - 10:15 & 17 & 18 & 14 & 3 & 5 & 1 \\
\hline 8 & 10:15 - 10:30 & 10 & 12 & 12 & 4 & 3 & 2 \\
\hline 9 & $10: 30-10: 45$ & 8 & 9 & 11 & 4 & 3 & 3 \\
\hline 10 & $10: 45-11: 00$ & 12 & 10 & 13 & 6 & 4 & 5 \\
\hline 11 & 11:00 - 11:15 & 16 & 13 & 16 & 2 & 3 & 4 \\
\hline 12 & 11:15 - 11:30 & 13 & 15 & 14 & 4 & 3 & 5 \\
\hline 13 & 11:30 - 11:45 & 8 & 9 & 13 & 4 & 7 & 2 \\
\hline 14 & $11: 45-12: 00$ & 12 & 14 & 11 & 1 & 2 & 1 \\
\hline 15 & $12: 00-12: 15$ & 9 & 11 & 9 & 2 & 1 & 2 \\
\hline 16 & $12: 15-12: 30$ & 13 & 11 & 11 & 6 & 4 & 4 \\
\hline 17 & $12: 30-12: 45$ & 12 & 9 & 14 & 7 & 8 & 3 \\
\hline 18 & $12: 45-13: 00$ & 9 & 13 & 10 & 5 & 6 & 2 \\
\hline 19 & $13: 00-13: 15$ & 19 & 15 & 14 & 2 & 3 & 1 \\
\hline 20 & $13: 15-13: 30$ & 10 & 10 & 14 & 1 & 1 & 1 \\
\hline 21 & $13: 30-13: 45$ & 11 & 8 & 17 & 6 & 4 & 3 \\
\hline 22 & $13: 45-14: 00$ & 12 & 16 & 13 & 6 & 4 & 5 \\
\hline 23 & $14: 00-14: 15$ & 16 & 18 & 11 & 1 & 4 & 2 \\
\hline 24 & $14: 15-14: 30$ & 10 & 4 & 17 & 5 & 2 & 5 \\
\hline 25 & $14: 30-14: 45$ & 15 & 15 & 17 & 3 & 4 & 4 \\
\hline 26 & $14: 45-15: 00$ & 17 & 19 & 15 & 4 & 5 & 3 \\
\hline 27 & $15: 00-15: 15$ & 18 & 16 & 17 & 3 & 2 & 4 \\
\hline 28 & $15: 15-15: 30$ & 14 & 17 & 14 & 1 & 2 & 3 \\
\hline 29 & $15: 30-15: 45$ & 11 & 15 & 10 & 5 & 5 & 3 \\
\hline 30 & $15: 45-16: 00$ & 16 & 14 & 12 & 3 & 2 & 4 \\
\hline 31 & $16: 00-16: 15$ & 17 & 14 & 15 & 3 & 2 & 5 \\
\hline 32 & $16: 15-16: 30$ & 17 & 19 & 13 & 4 & 5 & 4 \\
\hline 33 & $16: 30-16: 45$ & 9 & 11 & 11 & 2 & 3 & 3 \\
\hline 34 & $16: 45-17: 00$ & 14 & 15 & 10 & 3 & 3 & 3 \\
\hline 35 & $17: 00-17: 15$ & 18 & 15 & 13 & 2 & 1 & 4 \\
\hline 36 & $17: 15-17: 30$ & 15 & 17 & 11 & 4 & 5 & 3 \\
\hline 37 & $17: 30-17: 45$ & 15 & 10 & 16 & 4 & 3 & 4 \\
\hline 38 & $17: 45-18: 00$ & 14 & 15 & 15 & 1 & 3 & 2 \\
\hline 39 & $18: 00$ - 18:15 & 10 & 13 & 12 & 3 & 3 & 2 \\
\hline 40 & $18: 15-18: 30$ & 11 & 7 & 16 & 3 & 2 & 3 \\
\hline 41 & $18: 30-18: 45$ & 9 & 15 & 10 & 2 & 1 & 4 \\
\hline 42 & $18: 45-19: 00$ & 11 & 10 & 11 & 3 & 4 & 3 \\
\hline & Total & 550 & 546 & 553 & 147 & 147 & 131 \\
\hline & Rata-Rata & 13 & 13 & 13 & 4 & 4 & 3 \\
\hline
\end{tabular}




\begin{tabular}{|c|c|c|c|c|c|c|c|}
\hline \multirow{2}{*}{ NO. } & \multirow{2}{*}{ WAKTU } & \multicolumn{3}{|c|}{ MOTOR } & \multicolumn{3}{c|}{ MOBIL } \\
\cline { 3 - 8 } & & MASUK & KELUAR & TERTINGGAL & MASUK & KELUAR & TERTINGGAL \\
\hline \hline 1 & $08: 30-09: 00$ & 20 & 16 & 11 & 5 & 4 & 4 \\
\hline 2 & $09: 00-10: 00$ & 62 & 58 & 15 & 20 & 21 & 3 \\
\hline 3 & $10: 00-11: 00$ & 47 & 49 & 13 & 17 & 15 & 5 \\
\hline 4 & $11: 00-12: 00$ & 49 & 51 & 11 & 11 & 15 & 1 \\
\hline 5 & $12: 00-13: 00$ & 43 & 44 & 10 & 20 & 19 & 2 \\
\hline 6 & $13: 00-14: 00$ & 52 & 49 & 13 & 15 & 12 & 5 \\
\hline 7 & $14: 00-15: 00$ & 58 & 56 & 15 & 13 & 15 & 3 \\
\hline 8 & $15: 00-16: 00$ & 59 & 62 & 12 & 12 & 11 & 4 \\
\hline 9 & $16: 00-17: 00$ & 57 & 59 & 10 & 12 & 13 & 3 \\
\hline 10 & $17: 00-18: 00$ & 62 & 57 & 15 & 11 & 12 & 2 \\
\hline 11 & $18: 00-19: 00$ & 41 & 45 & 11 & 11 & 10 & 3 \\
\hline
\end{tabular}

\section{ANALISIS :}

Dilihat dari tabel di atas kendaraan beroda dua lebih banyak dibanding roda empat, apabila diamati secara sepintas terdapat beberapa waktu yang kendaraan beroda dua maupun empat padat masuk ke lokasi. Akan tetapi dilihat dari akumulasi kendaraan ((kendaraan terparkir+kendaraan yang masuk)-kendaraan yang keluar), waktu padat per 1 jam kendaraan yaitu pada waktu 16.0017.00 wita. 
(SELASA, 14 DESEMBER 2021)

\section{TABEL PER 15 MENIT}

\begin{tabular}{|c|c|c|c|c|c|c|c|}
\hline \multirow{2}{*}{ No. } & \multirow{2}{*}{\begin{tabular}{|c} 
INTERVAL WAKTU \\
PENGAMATAN
\end{tabular}} & \multicolumn{3}{|c|}{ MOTOR } & \multicolumn{3}{|c|}{ MOBIL } \\
\hline & & MASUK & KELUAR & TERTINGGAL & MASUK & KELUAR & TERTINGGAL \\
\hline \multicolumn{4}{|c|}{$<08: 30$} & 7 & & & \multirow{2}{*}{$\frac{4}{4}$} \\
\hline 1 & $08: 30-08: 45$ & 9 & 8 & 8 & 2 & 2 & \\
\hline 2 & 08:45 - 09:00 & 6 & 5 & 9 & 1 & 2 & 3 \\
\hline 3 & 09:00 - 09:15 & 7 & 8 & 8 & 1 & 1 & 3 \\
\hline 4 & 09:15 - 09:30 & 10 & 11 & 7 & 2 & 2 & 3 \\
\hline 5 & 09:30 - 09:45 & 11 & 9 & 9 & 1 & 2 & 2 \\
\hline 6 & 09:45 - 10:00 & 16 & 17 & 8 & 4 & 3 & 3 \\
\hline 7 & $10: 00$ - 10:15 & 14 & 14 & 8 & 1 & 3 & 1 \\
\hline 8 & $10: 15$ - 10:30 & 15 & 10 & 13 & 3 & 1 & 3 \\
\hline 9 & $10: 30$ - 10:45 & 19 & 15 & 17 & 2 & 3 & 2 \\
\hline 10 & $10: 45-11: 00$ & 15 & 19 & 13 & 3 & 2 & 3 \\
\hline 11 & $11: 00-11: 15$ & 14 & 13 & 14 & 1 & 3 & 1 \\
\hline 12 & $11: 15-11: 30$ & 10 & 9 & 15 & 1 & 1 & 1 \\
\hline 13 & $11: 30$ - 11:45 & 12 & 14 & 13 & 1 & 1 & 1 \\
\hline 14 & $11: 45-12: 00$ & 13 & 12 & 14 & 2 & 2 & 1 \\
\hline 15 & $12: 00-12: 15$ & 15 & 14 & 15 & 1 & 1 & 1 \\
\hline 16 & $12: 15-12: 30$ & 13 & 13 & 15 & 2 & 2 & 1 \\
\hline 17 & $12: 30-12: 45$ & 12 & 15 & 12 & 2 & 3 & 0 \\
\hline 18 & $12: 45-13: 00$ & 17 & 15 & 14 & 2 & 1 & 1 \\
\hline 19 & $13: 00$ - 13:15 & 18 & 16 & 16 & 2 & 1 & 2 \\
\hline 20 & $13: 15-13: 30$ & 13 & 12 & 17 & 1 & 1 & 2 \\
\hline 21 & $13: 30-13: 45$ & 16 & 19 & 14 & 3 & 1 & 4 \\
\hline 22 & $13: 45$ - 14:00 & 13 & 17 & 10 & 1 & 2 & 3 \\
\hline 23 & $14: 00-14: 15$ & 15 & 14 & 11 & 1 & 1 & 3 \\
\hline 24 & $14: 15-14: 30$ & 13 & 13 & 11 & 1 & 1 & 3 \\
\hline 25 & $14: 30-14: 45$ & 11 & 13 & 9 & 3 & 4 & 2 \\
\hline 26 & $14: 45-15: 00$ & 12 & 14 & 7 & 4 & 2 & 4 \\
\hline 27 & $15: 00-15: 15$ & 13 & 15 & 5 & 1 & 3 & 2 \\
\hline 28 & $15: 15-15: 30$ & 12 & 10 & 7 & 4 & 3 & 3 \\
\hline 29 & $15: 30$ - 15:45 & 10 & 9 & 8 & 5 & 5 & 3 \\
\hline 30 & $15: 45-16: 00$ & 12 & 13 & 7 & 1 & 2 & 2 \\
\hline 31 & $16: 00-16: 15$ & 11 & 12 & 6 & 1 & 2 & 1 \\
\hline 32 & $16: 15-16: 30$ & 12 & 11 & 7 & 2 & 1 & 2 \\
\hline 33 & $16: 30-16: 45$ & 11 & 10 & 8 & 3 & 1 & 4 \\
\hline 34 & $16: 45-17: 00$ & 9 & 7 & 10 & 2 & 3 & 3 \\
\hline 35 & $17: 00$ - 17:15 & 10 & 6 & 14 & 1 & 1 & 3 \\
\hline 36 & $17: 15-17: 30$ & 16 & 13 & 17 & 2 & 1 & 4 \\
\hline 37 & $17: 30$ - 17:45 & 14 & 14 & 17 & 1 & 2 & 3 \\
\hline 38 & $17: 45-18: 00$ & 12 & 16 & 13 & 1 & 2 & 2 \\
\hline 39 & $18: 00-18: 15$ & 12 & 13 & 12 & 2 & 2 & 2 \\
\hline 40 & $18: 15-18: 30$ & 14 & 13 & 13 & 1 & 1 & 2 \\
\hline 41 & $18: 30-18: 45$ & 14 & 15 & 12 & 1 & 1 & 2 \\
\hline 42 & $18: 45-19: 00$ & 13 & 15 & 10 & 3 & 2 & 3 \\
\hline & Total & 534 & 531 & 480 & 79 & 80 & 102 \\
\hline & Rata-Rata & 13 & 13 & 11 & 2 & 2 & 2 \\
\hline
\end{tabular}




\begin{tabular}{|c|c|c|c|c|c|c|c|}
\hline \multirow{2}{*}{ NO. } & \multirow{2}{*}{ WAKTU } & \multicolumn{3}{|c|}{ MOTOR } & \multicolumn{3}{c|}{ MOBIL } \\
\cline { 3 - 9 } & & MASUK & KELUAR & TERTINGGAL & MASUK & KELUAR & TERTINGGAL \\
\hline \hline 1 & $08: 30-09: 00$ & 15 & 13 & 9 & 3 & 4 & 3 \\
\hline 2 & $09: 00-10: 00$ & 44 & 45 & 8 & 8 & 8 & 3 \\
\hline 3 & $10: 00-11: 00$ & 63 & 58 & 13 & 9 & 9 & 3 \\
\hline 4 & $11: 00-12: 00$ & 49 & 48 & 14 & 5 & 7 & 1 \\
\hline 5 & $12: 00-13: 00$ & 57 & 57 & 14 & 7 & 7 & 1 \\
\hline 6 & $13: 00-14: 00$ & 60 & 64 & 10 & 7 & 5 & 3 \\
\hline 7 & $14: 00-15: 00$ & 51 & 54 & 7 & 9 & 8 & 4 \\
\hline 8 & $15: 00-16: 00$ & 47 & 47 & 7 & 11 & 13 & 2 \\
\hline 9 & $16: 00-17: 00$ & 43 & 40 & 10 & 8 & 7 & 3 \\
\hline 10 & $17: 00-18: 00$ & 52 & 49 & 13 & 5 & 6 & 2 \\
\hline 11 & $18: 00-19: 00$ & 53 & 56 & 10 & 7 & & 6 \\
\hline
\end{tabular}

\section{ANALISIS :}

Dilihat dari tabel di atas kendaraan beroda dua lebih banyak dibanding roda empat, apabila diamati secara sepintas terdapat beberapa waktu yang kendaraan beroda dua maupun empat padat masuk ke lokasi. Akan tetapi dilihat dari akumulasi kendaraan ((kendaraan terparkir+kendaraan yang masuk)-kendaraan yang keluar), waktu padat per 1 jam kendaraan yaitu pada waktu 10.0011.00 wita.

\section{Kebutuhan Parkiran :}

- Lahan parkir ini bisa dikatakan sudah memenuhi standar karena bisa menampung kendaraan yang masuk kelokasi tersebut. Tapi apabila kendaraan tidak tertata dengan baik maka parkiran tersebut tidak akan muat.

- Untuk kapasitas maksimal kendaraan roda empat parkir di alfamidi super yaitu hanya 8 unit, sedangkan kendaraan roda dua maksimal 30 unit yang bisa parkir dalam kurung waktu bersamaan. 


\section{BAB IV \\ PENUTUP}

\section{A. KESIMPULAN}

- Dari hasil survei yang dilakukan selama 4 hari ini,kondisi parkir yang berada di jl. Jend Sudirman khususnya di Alfamidi Super kondisi parkirnya itu sudah memenuhi. Meskipun parkiran tersebut biasa tidak tertata dengan baik dikarenakan tidak adanya petugas parkir yang mengatur kendaraan.

- Dan hasil survei yang dilakukan selama 4 hari ini bisa disimpulkan bahwa kendaraan yang padat itu berada pada hari kerja dibandingkan dengan pada hari libur.

\section{B. SARAN}

- Sebaiknya pada Alfamidi Super terdapat satu orang juru parkir supaya parkiran tertata dengan baik. 


\section{DAFTAR PUSTAKA}

Fisu, A.A (2018). Analisis Lokasi Pada Perencanaan Terminal Topoyo Mamuju Tengah. PENA TEKNIK : Jurnal Ilmiah Ilmu-Ilmu Teknik,3(1),112.

Fisu, A.A (2019). Tinjauan Kecelakaan Lalu Lintas Antar Wilayah Pada Jalan Trans Provinsi Sulawesi Selatan. PENA TEKNIK : Jurnal Ilmiah IlmuIlmu Teknik,4(1),53-65.

Ahmad Munawar.2000.Panduan Pengamatan dan Pengambilan Data, Yogyakarta,Simposium III Forum Studi Transportasi antar Perguruan Tinggi.

Morlok,E.K. (1995). Pengantar Teknik dan Perencanaan Transportasi, penerbit Erlanga, Jakarta

Tamin, OZ., (2000). Perencanaan dan pemodelan Transportasi, Edisi Kedua, Penerbit ITB, Bandung.

Abubakar, dkk. 1997. Menuju Lalulintas dan Angkutan Jalan yang Tertip. Jakarta : Direktorat Jendral Perhubungan Darat.

Rahma, N.2015. Analisa Karakteristik dan Kebutuhan Parkir Motor di kampus terpadu Universitas Islam Indonesia. Tugas Akhir. (Tidak Diterbitkan). Universitas Isalam Indonesia. Yogyakarata.

Nugroho, A. 2013. Estimasi Perhitungan Peparkiran di Stasiun Kota Depok.Tesis. Universitas Gunadarma, Depok.

Dayana, Eva. (2012). Analisis kebutuhan parkir kendaraan di Bandara Husein Sastranegara. Bandung : Fakultas Teknik Sipil dan Lingkungan Institut Teknologi Bandung

Rosyadi, Muhammad. (2007), “Analisis Tingkat Pelayanan Parkir Terminal Regional Daya di Kota Makassar", Program Pascasarjana Universitas Hasanuddin Makassar.

Taju, D.R.J. (1996).” Karekteristik Kebutuhan Parkir pada Rumah Sakit di Bandung”, Institut Teknologi Bandung, Bandung 